\title{
Effect of Desulfurization Ash with Different Gypsum Content on Rheology Characteristic, Hydration Structure and Rebar Protection of Cement Based Materials
}

\author{
Xiaodong $\mathrm{Wen}^{1, *}$, Yong $\mathrm{Yi}^{1}$, Guosong $\mathrm{Li}^{1}$ and Zhinan $\mathrm{Gao}^{2}$ \\ ${ }^{1}$ Ningbo University of Technology, Ningbo Key Laboratory of Concrete structure Durability, 315016, China \\ ${ }^{2}$ School of Mechanics \& Civil Engineering; China University of Mining \& Technology, 100083, China
}

\begin{abstract}
Depending on the desulfurization reaction temperature, it can be divided into fly ash generated at hightemperature furnace zone and at low-temperature flue gas zone. For simulating those two kinds of desulfurization ash, the ordinary fly ash mixed with different weight percentage of $\mathrm{CaSO}_{4} \cdot 2 \mathrm{H}_{2} \mathrm{O}$ is divided into 2 groups, the first group is followed by calcining at $900^{\circ} \mathrm{C}$, another drying at $100^{\circ} \mathrm{C}$. And then by the experiment of workability, strength and steel rebar protection, the effect of morphology and amount of gypsum on material properties and the pretreatment method are studied. The results show that: compared with ordinary fly ash, those two kinds of desulfurization ash can improve workability, but the improving ability of desulfurization ash at high-temperature furnace zone weaker than another's, in addition, amount of gypsum in desulfurization ash on fluidity has a threshold; Secondly, the structure forming of the sample with 10\% gypsum drying at $100^{\circ} \mathrm{C}$ are faster than that of control sample, however the structure forming is slower than the control sample when gypsum drying at $100^{\circ} \mathrm{C}$ increase to $20 \%$. As for gypsum calcining at $900^{\circ} \mathrm{C}$, the structure forming of sample with 20 mass\% gypsum are fastest, with 10 mass\% gypsum follows closely next, the control sample falls behind. Thirdly, desulfurization ash can decrease strength, and the early strength of desulfurization ash at high-temperature furnace zone higher than another's, but the development trend of later strength is in the opposite direction. Lastly, those two kinds of desulfurization ash are harmless for steel rebar, and the steel rebar's passive film compactness is followed desulfurization ash formed at low-temperature flue gas zone>desulfurization ash formed at high-temperature furnace zone>ordinary fly ash.
\end{abstract}

Keywords: Desulfurization ash, simulation, structure, steel rebar protection.

\section{INTRODUCTION}

Under the control of acid gases $\left(\mathrm{SO}_{2}\right.$ and $\left.\mathrm{NO}_{\mathrm{x}}\right)$ emissions, more and more coal fired boilers use desulphurization technology, and there will be more desulfurization ash discharged, such that Shanghai generated million ton of desulfurization ash in 2009, what's more, every year it will keep more than million ton after 2010 year [1]. While the most of it is put in the open-air or abandoned, this will bring about wasting of resources and severe secondary pollution. Today the large number of cement-based materials is need by humans engineering activities every year, such as cement grouting material with more than million ton, so it helps if that waste can be used to the cement-based materials.

At present most of the research in home and abroad [2-8], its effect on the property of cement material is studied by changing the quantity of desulfurization ash. But in the fact, the coal-quality is different between different districts, and it is even varied in the same power plant, thus the component of desulfurization ash are variations, and its quality will become instability. Besides the desulfurization ash can be

\footnotetext{
*Address correspondence to this author at the School of Building and Civil Engineering, Ningbo University of Technology, Ningbo, 315016, China; Tel: +86-574-87081248(office), +86-1586740136 (Mobile); Fax: +86-57487081278; E-mail: wenxiaodong8@163.com
}

divided into two kinds according to temperature of desulphurization reaction, that is one generated at high-temperature furnace zone (the temperature in the inner width of furnace hearth will be kept at $850-1150^{\circ} \mathrm{C}$ ) and another generated at low-temperature flue gas zone (the temperature in flue gas between $50-150^{\circ} \mathrm{C}$ ). And different temperature make desulfurization ash has different components and morphology, at high temperature, the fly ash is mixed with $\mathrm{CaSO}_{4}$, while in low temperature it is mixed with $\mathrm{CaSO}_{4} \cdot 2 \mathrm{H}_{2} \mathrm{O}$.

Therefore it will be divided and simulated according to desulfurization reaction temperature, and then effects of it with different gypsum content and heated different temperature on cement material performance are studied for reusing and application of desulfurization ash.

\section{MATERIALS AND EXPERIMENTAL PROGRAM}

\subsection{Materials}

The materials used in this study consisted of a Portland Cement grade 42.5, a chemical grade gypsum, standard sand furnished by Xiamen ISO Standard Sand Co., Ltd., and a Class II fly ash. The chemical composition of the cement and fly ash is shown Table $\mathbf{1}$.

\subsection{Experimental Methods}

Fluidity tests and strength tests were respectively carried out in accordance to GB/ T2419- 2005 "Test method for flu- 
Table 1. Chemical Composition of Cementitious Material, wt. \%

\begin{tabular}{|c|c|c|c|c|c|c|c|c|c|}
\hline & $\mathbf{S i O}_{2}$ & $\mathrm{Al}_{2} \mathbf{O}_{3}$ & $\mathbf{F e}_{2} \mathbf{O}_{3}$ & $\mathbf{C a O}$ & $\mathbf{M g O}$ & $\mathbf{S O}_{3}$ & $\mathbf{K}_{2} \mathbf{O}$ & $\mathbf{N a}_{2} \mathbf{O}$ & $\mathbf{L o s s}$ \\
\hline \hline P.II 42.5 & 21.2 & 4.98 & 5.03 & 64.43 & 1.45 & 1.02 & 0.75 & 0.08 & 1.06 \\
\hline II-fly ash & 52.42 & 30.31 & 4.89 & 2.62 & 0.91 & - & 1.03 & 0.53 & 5.75 \\
\hline
\end{tabular}

idity of cement mortar" and GB/ T17671-1999 "method of testing cements- Determination of strength". Initial hydration process and structure forming of Portland cement was tested by non-contacting electrical resistivity device. Under the induction electric field, the ion transmission, diffusion and the situation of the structure forming were tested. An anodic polarization test for evaluating on ability of reinforcement protection was done referring to JTJ270-98 "Testing code of Concrete for Port and Waterwog Engineering".

\subsection{Research Approach}

Desulfurization ash has been reported that the gypsum content varied between 10 and 20 mass \% fly ash from previous articles, therefore three mixtures containing respectively 10, 15 and 20 mass $\% \mathrm{CaSO}_{4} \cdot 2 \mathrm{H}_{2} \mathrm{O}$ are chose in this paper. Simultaneously, those mixtures are divided into 2 groups; the first group is followed by calcining at $900^{\circ} \mathrm{C}$, another drying at $100^{\circ} \mathrm{C}$ according to desulfurization reaction temperature for simulating two kinds of desulfurization ash generated at high-temperature furnace zone and at lowtemperature flue gas zone. Finally the fly ash replacement of cement was usually 20 mass $\%$ in the actual project, so the control specimen is preparing by replacing 20 mass $\%$ of the cement by fly ash, comparison of samples are mixed with 20 mass \% desulfurization ash. The water/binder ratio by mass was 0.5 , and all the mixes had 1 part binder to 2.75 parts of sand by mass.

\section{RESULTS AND DISCUSSION}

\subsection{Fluidity}

From Fig. (1), the fluidity of mortar containing desulfurization ash generated at low-temperature flue gas zone has a

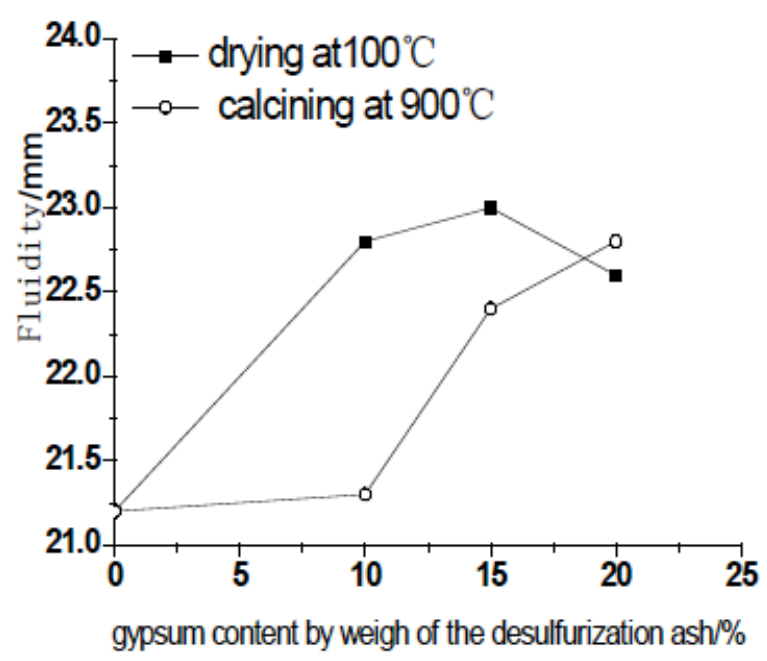

Fig. (1). Effect of desulfurization ash with different desulfurization temperature and gypsum content on the fluidity. critical point that the its gypsum content less than $15 \%$ improve the fluidity, however, increasing it further reduce the fluidity. As for mortar mixed desulfurization ash generated at high-temperature furnace zone, this point can not be found, and the fluidity increases with increasing gypsum up to $20 \%$ (by weigh of the desulfurization ash). Those show that: compared to ordinary fly ash, both kinds of desulfurization ash with gypsum content less than $20 \%$ can improve the fluidity. Besides it can be found that the fluidity enhancement of samples with desulfurization ash generated at lowtemperature flue gas zone is higher than ones of desulfurization ash generated at high-temperature furnace zone below the critical point, such as: for the gypsum content of 10 mass $\%$, their fluidity are respectively 230 and $212 \mathrm{~mm}$.

The reason is: with an appropriate amount of $\mathrm{Ca}^{2+}$ and $\mathrm{SO}_{4}{ }^{2-}$ supplied by the dissolution of gypsum, the formation of ettringite slows down the hydration of $\mathrm{C}_{3} \mathrm{~A}$ by creating a diffusion barrier around $\mathrm{C}_{3} \mathrm{~A}$ grains, and then the fluidity increases. But if excessive gypsum is supplied, the formation of secondary gypsum crystals and excess ettringite will roset cluster and overlap one another for formateing the network structure, and reduce the fluidity; Secondarily, the hemihydrates $\left(\mathrm{CaSO}_{4} \cdot 0.5 \mathrm{H}_{2} \mathrm{O}\right)$ is produced except for insoluble anhydrate when gypsum heated in the furnace, thereby the hydration of gypsum hemi-hydrate take place in the sample containing desulfurization ash generated at high-temperature furnace zone and hence to a increase unit water demand of the cement. Besides, the gypsum dissolution rates in desulfurization ash generated at high-temperature furnace zone is low compared to another's, thus require more this calcined gypsum for the saturated concentrations of $\mathrm{Ca}^{2+}$ and $\mathrm{SO}_{4}{ }^{2-}$ ions in liquid phase.

\subsection{The Structure Forming}

During the process of cement hydration, the forming and developing of structure are different according to the different mineral component of cement. By many experiments, the regular trend and rule is shown on resistivity curve along with cement hydration, as shown in Fig. (2). It can be observed from the figures that there exist some characteristic points in the curves of the resistivity. Initially, the curve drop down to a minimum point, then turn into the balance state, and start to rise. After the rapid rising, both curves tend to smooth. So according to the structure forming model of cement initial hydration can be divided in three stages ( $\mathrm{S}$ model) [9], i.e. Solution-solution equilibrium phase; Structure forming phase; Structure stabilizing phase.

Physical significance of the S-model reflects the development of the ion transformation and diffuse, the structure building trough the pore forming and filling during the cement hydration. So as a structure parameter, S-model dem- 


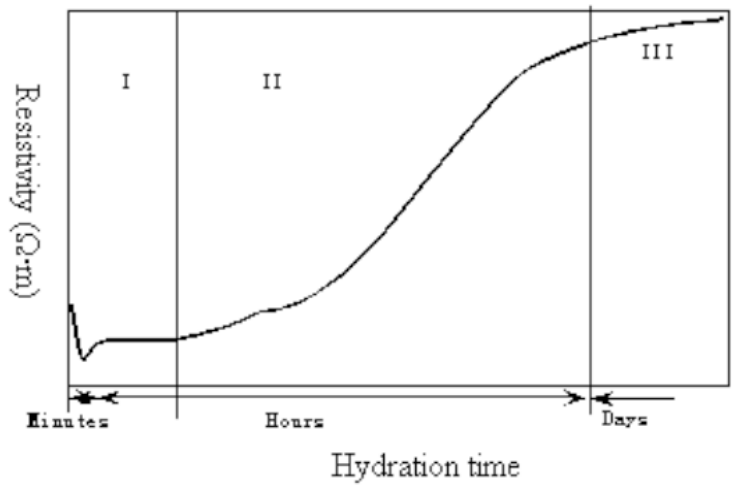

Notes: I: Solution-solution equilibrium phase; II: Structure forming phase; III: Structure stabilizing phase

Fig. (2). Characteristic of hydration resistivity curve.

onstrates the influences of different factors on the structure of cement stone.

Fig. (3) shows the resistivity curve of specimens with an addition of $10-20$ mass $\%$ gypsum drying at $100^{\circ} \mathrm{C}$ and the change in resistivity of specimens with an addition of 10-20 mass \% gypsum calcining at $900^{\circ} \mathrm{C}$ shown in Fig. (4). It can be seen from it that the resistivity curves of different specimen develop according to the S-model shown in Fig. (2). But there is an evidence difference on the resistivity because of the difference of gypsum contents and temperature. The structure forming of the sample with $10 \%$ gypsum drying at $100^{\circ} \mathrm{C}$ are faster than that of control sample, however the

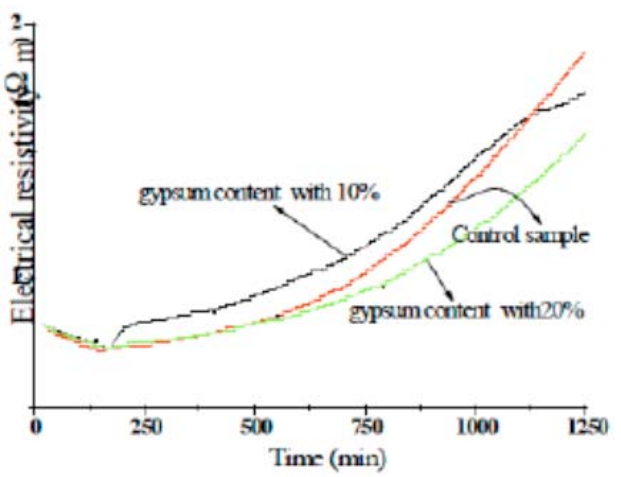

Fig. (3). Resistivity development of specimens with gypsum drying at $100^{\circ} \mathrm{C}$.

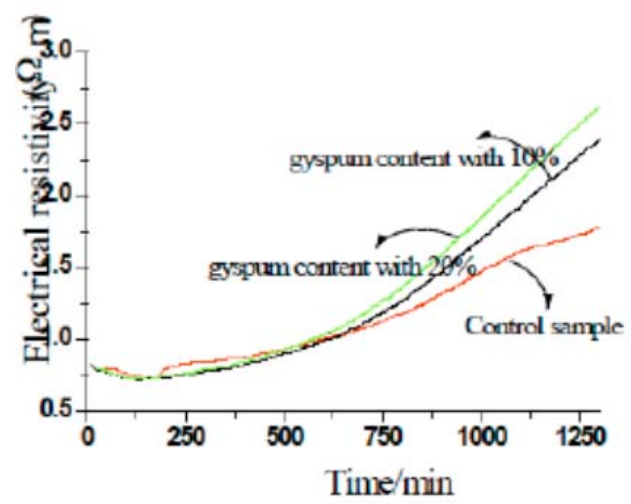

Fig. (4). Resistivity development of specimens with gypsum calcining at $900^{\circ} \mathrm{C}$. structure forming is slower than the control sample when gypsum drying at $100^{\circ} \mathrm{C}$ increase to $20 \%$. As for gypsum calcining at $900^{\circ} \mathrm{C}$, the structure forming of sample with 20 mass \% gyspum are fastest, with 10 mass\% gypsum follows closely next, the control sample falls behind. The result implies that moderate gypsum can accelerate fly ash hydration and accelerates the initial structure formation, but the gypsum overdose can retard the cement hydration. And the threshold limit value of gypsum calcining at $900^{\circ} \mathrm{C}$ is lower than that of drying at $100^{\circ} \mathrm{C}$ due that the dissolution of gypsum calcining at $900^{\circ} \mathrm{C}$ is low compared to another's.

\subsection{Strength}

The cubes were tested for their compressive and flexural strength at 7 days and 28 days. Figs. (5-6) shows the compressive and flexural strength verses the gypsum content for both kinds of desulfurization ash that the strength decreases with increasing the gypsum content, and 7 days strength of samples with desulfurization ash generated at hightemperature furnace zone is slightly more than that at lowtemperature flue gas zone however 28 days strength of the former is more than the latter. Thus it is clear that desulfurization ash can decline strength compared to ordinary fly ash, and the contribution of desulfurization ash generated at lowtemperature flue gas zone to lateral strength is more than one at high-temperature furnace zone.

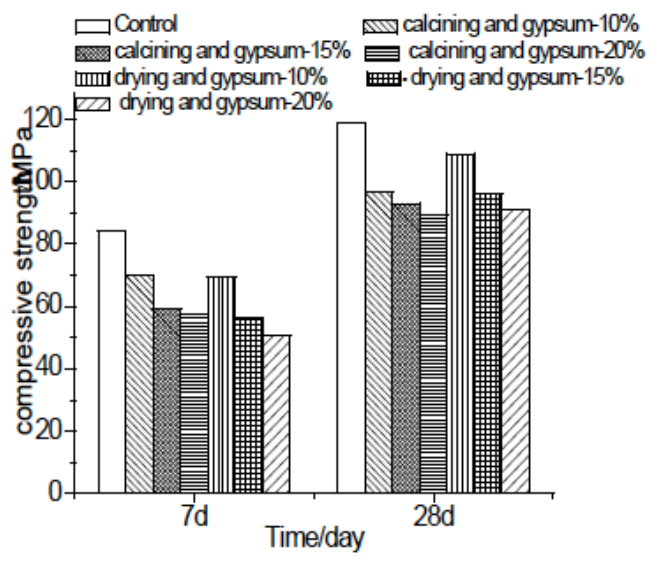

Fig. (5). Effect of desulfurization ash with different desulfurization temperature and gypsum content on the compressive strength.

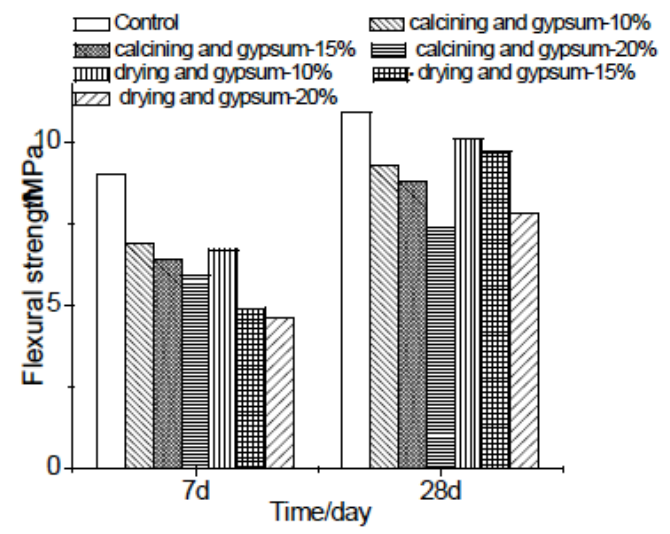

Fig. (6). Effect of desulfurization ash with different desulfurization temperature and gypsum content on the flexural strength. 
As for the reason, $\mathrm{Ca}^{2+}$ and $\mathrm{SO}_{4}{ }^{2-}$ lions increased so fast in liquid phase that the formation of ettringite is accelerated, then the diffusion processed of hydration products become slower and secondary gypsum crystals formed with a lowstrength state exist in harden body, and cause strength of the samples decrease. On the other hand, the ability of gypsum drying at $100^{\circ} \mathrm{C}$ to impede hydration products proliferation is stronger than the gypsum calcining at $900^{\circ} \mathrm{C}$ because of the higher solubility and dissolution rate of the gypsum drying at $100^{\circ} \mathrm{C}$ so that 7 days strength of samples containing desulfurization ash generated at high-temperature furnace zone is slightly more than ones mixed with desulfurization ash generated at low-temperature flue gas zone, while its 28 days strength is less than the latter because its structure is damaged by the ettringite formed in later period by the lower solubility and dissolution rate of gypsum calcining at $900^{\circ} \mathrm{C}$, and the long term supply of $\mathrm{Ca}^{2}+$ and $\mathrm{SO}_{4}{ }^{2-}$ lions.

\subsection{Reinforcement Protection}

Reinforcing bar corrosion process can be considered a corrosion cell, and the method of anode polarization curves can reflect anodic reaction rate, as shown in equation (1), through the potential changes of the reinforcing steel during the polarization process applying a constant current.

$\mathrm{Fe}-2 \mathrm{e}^{-}=\mathrm{Fe}^{2+}$

Fig. (7) shows anodic polarization potential verses time. At an early stage of applied current, electric potential of the samples is all greatly increased because of the anodic polarization of reinforced by anode current, soon after the differences is shown in the potential-time curve for different components of the samples.

If the reinforcing bar surface doesn't form the passive film, $\mathrm{Fe}^{2+}$ converted by an iron atom according to equation (1) will bind $\mathrm{OH}^{-}$ion, or will be carried far from the reinforcing bar by $\mathrm{Cl}^{-}$ion, and the potential of reinforcing bar will decrease because the electrons lost by iron atom are remained in the internal reinforcing bar.

From Fig. (5), at 6 minutes the potential of each sample has reached $500 \mathrm{mv}$, and after 15 minutes decrease in potential are all less than 50mv. Those results show each sample of reinforcing bar passive film is not damaged. Compact passive film can impede diffusion of $\mathrm{Fe}^{2+}$ ions to the solution. And the higher polarization potential, metal ions need over-

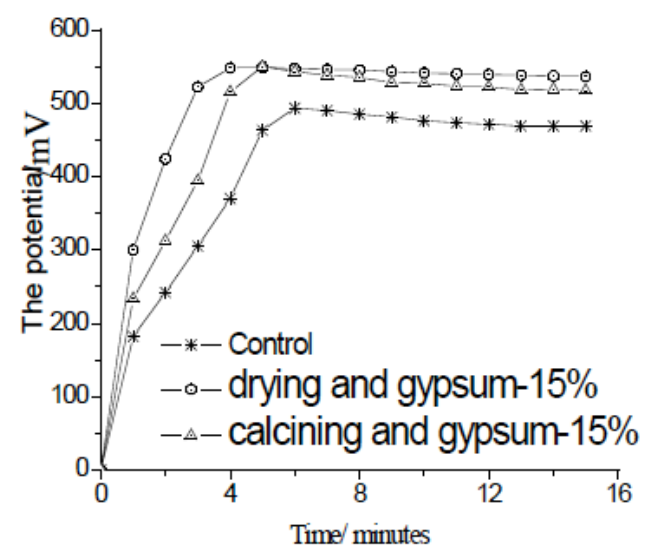

Fig. (7). Anodic polarization potential verses time. come the higher energy barrier for entering the solution [10]. So both kinds of desulfurization ash do not harm the reinforcing bar, and according to anodic polarization potential the density of passive films formed the samples mixed desulfurization ash generated at low-temperature flue gas zone is highest, followed by desulfurization ash generated at hightemperature furnace zone, ordinary fly ash.

\section{CONCLUSIONS}

According to the temperature of desulphurization reaction desulfurization ash are simulated, and then effects of it with different gypsum content and heated different temperature on fluidity, strength and reinforcement protection of cement material are studied. This article's main conclusions can be drawn are as follows:

1) Fluidity. The fluidity of mortar containing desulfurization ash generated at low-temperature flue gas zone has a critical point that the its gypsum content less than this point improve the fluidity, however, increasing it further reduce the fluidity. As for mortar mixed desulfurization ash generated at high-temperature furnace zone, this point can not be found. Both kinds of the desulfurization ash can improve the fluidity Compared with the ordinary fly ash, but the fluidity enhancement of samples with desulfurization ash generated at low-temperature flue gas zone is higher than another desulfurization ash below the critical point.

2) The structure forming. The structure forming of the sample with $10 \%$ gypsum drying at $100^{\circ} \mathrm{C}$ are faster than that of control sample, however the structure forming is slower than the control sample when gypsum drying at $100^{\circ} \mathrm{C}$ increase to $20 \%$. As for gypsum calcining at $900^{\circ} \mathrm{C}$, the structure forming of sample with 20 mass\% gypsum are fastest, with 10 mass\% gypsum follows closely next, the control sample falls behind.

3) Strength. Desulfurization ash can decline strength compared to ordinary fly ash, and 7days strength of samples with desulfurization ash generated at high-temperature furnace zone is slightly more than that at low-temperature flue gas zone however 28 days strength of the former is more than the latter.

4) Reinforcement protection. Both kinds of desulfurization ash do not harm the reinforcing bar, and according to anodic polarization potential the density of passive films formed the samples mixed desulfurization ash generated at low-temperature flue gas zone is highest, followed by desulfurization ash generated at high-temperature furnace zone, ordinary fly ash.

\section{ACKNOWLEDGMENTS}

The authors would like to thank Ningbo Municipal Natural Science Foundation (2008A610100) and Educational Commission of Zhejiang Province (Z201016586) for financial support.

\section{REFERENCES}

[1] H. Hongzhu, Z. Ming, and Q. Xianlin, "Investigation into shanghai comprehensive utilization of fly ash and desulfurized slag", Coal Ash China, vol. 19, pp. 39-42, May 2007.

[2] C. Huilong, L. Xinai, and Y. Shouqi, "Mass transfer mechanism of charged lime droplets and $\mathrm{SO}_{2}$ ", J. Jiangsu. Univ. Nat. Sci., vol. 29, pp. 317-322, April 2008. 
[3] S. Huisheng, and L. Hongyuan, "Resource recovery of flue gas desulphurization gypsumin slag cement", J. Tongji. Univ. (Natural Science), vol. 36, pp. 66-70, January 2008.

[4] S. Xiaofang, X. Junpeng, and T. Minde, "Three kinds of desulfurization residue on cement performance", Cement China, pp. 11-12, Oct 2005.

[5] W. Zhi, "Study on Properties and Utilization in Building Materials of Bottom Ashes from Circulating Fluidized Bed Combustion", Ph. D. thesis, Chongqing University, China, 2002.

[6] B. Pacewska, G. Blonkowski, and I. Wilińska, "Investigation of the influence of different fly ash on cement hydration", Thermal Anal. Calor., vol. 86, pp. 179-186, 2006.
[7] setting time of cement", Cement China, vol. 5, pp. 1-6, May 2005.

8] G. Bin, G. Jingxuan, and R. Ailing, "Impact factors of gelatinous material strength prepared by sintering", Environ. Sci. Technol., vol. 32, pp. 39-43, 2009.

[9] M. Baoguo, D. Rongzhen, and Z. Li, "Research of the initial hydration process and structure formation of portland cement", J. Wuhan Univ. Technol., vol. 10, pp. 3-4, July 2004.

[10] H. Yedong, Introduction to Corrosion and Protection [M]. Beijing: Machinery Industry Press, 2005. (InChinese)

(C) Wen et al.; Licensee Bentham Open.

This is an open access article licensed under the terms of the Creative Commons Attribution Non-Commercial License (http://creativecommons.org/licenses/by-nc/3.0/) which permits unrestricted, non-commercial use, distribution and reproduction in any medium, provided the work is properly cited. 